\title{
Correction to: Cancer-specific survival by stage of bladder cancer and factors collected by Mallorca Cancer Registry associated to survival
}

\author{
J. Ripoll ${ }^{1,2}$, M. Ramos ${ }^{2,3^{*}}$, J. Montaño ${ }^{2,4}$, J. Pons ${ }^{3}$, A. Ameijide ${ }^{5}$ and P. Franch ${ }^{2,3}$ \\ Correction to: BMC Cancer 21, 676 (2021) \\ https://doi.org/10.1186/s12885-021-08418-y
}

Following publication of the original article [1], the authors noticed a missing affiliation for J Ripoll, M Ramos, J Montaño and P Franch. The affiliation is as follows:

Balearic Islands Health Research Institute (IdISBa), 07120 Palma de Mallorca, Illes Balears, Spain

The affiliations have been correctly published in this correction and the original article [1] has been updated.

\section{Author details}

'Primary Care Research Unit of Mallorca, Balearic Health Service, Palma, Spain. ${ }^{2}$ Balearic Islands Health Research Institute (IdISBa), 07120 Palma de Mallorca, Illes Balears, Spain. ${ }^{3}$ Mallorca Cancer Registry, Balearic Islands Public Health Department, Palma, Spain. ${ }^{4}$ University of the Balearic Islands, Palma, Spain. ${ }^{5}$ Tarragona Cancer Registry, Cancer Epidemiology and Prevention Service, Sant Joan de Reus University Hospital, IISPV, Reus, Spain.

Published online: 26 August 2021

\section{Reference}

1. Ripoll J, Ramos M, Montaño J, Pons J, Ameijide A, Franch P. Cancer-specific survival by stage of bladder cancer and factors collected by Mallorca Cancer Registry associated to survival. BMC Cancer. 2021;21:676 https://doi.org/1 0.1186/s12885-021-08418-y

The original article can be found online at https://doi.org/10.1186/s12885021-08418-y.

*Correspondence: mramos@dgsanita.caib.es

${ }^{2}$ Balearic Islands Health Research Institute (IdISBa), 07120 Palma de Mallorca, Illes Balears, Spain

${ }^{3}$ Mallorca Cancer Registry, Balearic Islands Public Health Department, Palma, Spain

Full list of author information is available at the end of the article

(c) The Author(s). 2021 Open Access This article is licensed under a Creative Commons Attribution 4.0 International License, which permits use, sharing, adaptation, distribution and reproduction in any medium or format, as long as you give appropriate credit to the original author(s) and the source, provide a link to the Creative Commons licence, and indicate if changes were made. The images or other third party material in this article are included in the article's Creative Commons licence, unless indicated otherwise in a credit line to the material. If material is not included in the article's Creative Commons licence and your intended use is not permitted by statutory regulation or exceeds the permitted use, you will need to obtain permission directly from the copyright holder. To view a copy of this licence, visit http://creativecommons.org/licenses/by/4.0/ The Creative Commons Public Domain Dedication waiver (http://creativecommons.org/publicdomain/zero/1.0/) applies to the data made available in this article, unless otherwise stated in a credit line to the data. 